\title{
Translation and Localization of Microtoponyms (Based on Russian and English-Language Texts of Online Tourism Discourse)
}

\author{
Irina D. Romadina - Vera A. Mityagina
}

DOI: 10.18355/XL.2017.10.02.10

\begin{abstract}
This article deals with the problem of translation and localization of microtoponyms, which are the names of human-created objects of geographical space such as squares, parks, museums, theaters, avenues within the online tourism discourse. The study of existing techniques of these lexical units' translation functioning in parallel Russian and English hypertexts, the authors revealed the absence of a uniform approach to the use of the transcription, loan, and description techniques, and proposed a productive from the functional viewpoint method of localization.
\end{abstract}

Key words: localization, microtoponym, tourism discourse, translation technique, verbal semiotics

\section{Introduction}

The transfer of tourism discourse to the Internet space contributed to globalization of discourse practices in this sphere and initiated large-scale translation activity, which has become an important tool for the development of the tourism industry. The expansion of cross-language and cross-cultural contacts in the global communicative contexts of tourist practice determined the significance of the process of translating texts that promote different tourist destinations around the world. In these conditions the higher translation standards in the researched industry are necessary to ensure information accessibility and comprehension by the representatives of other cultures. The following genres of tourism discourse represent the translators' objects: information and advertising materials (print brochures, hypertexts of tourist portals, websites of travel agencies, websites of certain tourist destinations and cultural objects, websites of museums), guidebooks as a part of the websites' virtual space, travel blogs published in international journals (National Geographic, Geo, etc.), excursions. Travel writing has been always characterized by ethnic and cultural narration, and over a few centuries of genre transformations this focus remained the dominating feature of tourism discourse in the context of emphasizing local identities. The culture starts to reveal its identity more intensely when it is brought into a certain cultural community, and as a result, this culture gets encoded as "unique" and "special" (Lotman, 1992). In this context, the opposition of local and global is becoming a peculiar characteristic of the virtual tourism discourse and, in particular, such imperative genres as guidebooks, information and advertising materials.

\section{Localization as a new branch of translation studies}

The emergence of the phenomenon of localization is associated with the technological revolution and the expansion of companies' activity up to the level of international and global corporations, which resulted in the need to develop technologies of software and manuals adaptation in accordance with economic, linguistic and cultural parameters. These technologies have provided the customers from different countries with the access to goods and services presented on the world market, and in this direction of organized business activity the translation is only an element of the

112

XLinguae Journal, Volume 10 Issue 2, April 2017, ISSN 1337-8384 
general process of linguacultural adaptation (also including technical expertise, work in the field of terminology, programming, design, marketing, etc.) aimed at the realization of products in foreign markets. The elements that need to be localized and are not related to translation procedures include time formats, dates, numbers, currency, legal, tax and environmental requirements, as well as some of the technical aspects of the design (color, page size, keyboard layout, etc.), applicable to the products in different countries. Today the objects of localization represent different computermediated resources used by an audience of another country:

1. Software (including linguistic training program);

2. Websites (international portals, business cards, online shops, etc.);

3. Computer games;

4. Multimedia;

5. Marketing and PR-materials (brochures, presentations of companies, etc.) (Batyukova, 2011).

The trend of integrating the concept of localization by translation studies observed in the last decade is connected with the search for the best ways to ensure intercultural polylogue currently proceeding at an unprecedented level and characterized, first of all, by corporate communication between companies and clients. Pragmatic linguistics and cultural linguistics, which became the leading interdisciplinary fields of discourse research, outlined the problems of translation conditioned by addressee characteristics and were subsequently recognized to be the tasks extremely important for creating multilingual content of corporate websites.

The research on translation and localization (Androutsopoulos 2010; JiménezCrespo 2016; Mityagina 2014; Usacheva 2012; Shurlina 2014; Shadrin 2015) provide various definitions of this process. Localization is:

- a discourse process aimed at changing media content (Androut sopoulos, 2010);

- a complex form of pragmatic adaptation (Mityagina, 2014: 347);

- a new branch of technical translation (Shurlina, 2014: 83);

- adaptation of a "generalized" text to the whole variety of new pur poses and application spheres arising in moderre

realia (Shadrin, 2015).

Such research are extremely important for the Russian and foreign translation studies, because the hypertexts of international websites are often translated according to the principle of language symmetry and turn to be controversial in terms of communicative and pragmatic adequacy. E. Pym puts forward the issue on recognizing the phenomenon of localization the newest paradigm of translation studies, the main provisions of which give an idea of the extent to which translation practices have changed in the context of economic globalization of society (Pym, 2014: 182). As the researcher points out, the innovation features of localization include the one-to-many translation model, the need to translate from an internationalized version, as well as the automation of the translation process by means of modern technology (Pym 2014). The combination of these characteristics within a written form of intercultural transfer is actually an unprecedented one.

\section{Problems of translation and localization of microtoponyms}

A special role in the process of translating and localizing tourist hypertexts is played by linguacultural adaptation of microtoponyms - the proper names of human-created environment objects, which take part in implementing informative func- 
tion of guidebooks, advertising materials and encyclopedic articles about local attractions. The microtoponyms include the names of squares, parks, museums, theaters and other cultural facilities, which create the attractive image of a city or a certain tourist destination:

Heaton Hall is a magnificent 18thC country house set in the rolling landscape of Heaton Park ${ }^{15}$;

- $\quad$ Now home to the British Crown Jewels, the Tower of London was built by William the Conqueror in 1078. It served as a prison from 1100 to the mid twentieth century.Today the Tower of London is one of the most popular London tourist attractions ${ }^{16}$;

- $\quad$ the U.S. Astronaut Hall of Fame features more exhibits, with personal memorabilia displayed alongside things that will amaze you, such as the actual Apollo 14 command module Kitty Hawk, its plaque bearing the simple inscription 'This spacecraft flew to the moon and back January 31-February 9, $1971^{, 17}$.

Each city shapes the original symbolic field with a specific semantics (Vasilyeva, 2016: 140), and in this sense microtoponyms, like any proper names, reflect the ethnic and cultural meanings and perform, above all, the cognitive function, thus being among the most meaningful components in the semiotic space of a tourist hypertext. The translator should have knowledge about semantics and lexical sets in source language to develop strategies for dealing with non-equivalence in semantic field and should not forget that language and culture are closely related and both aspects must be considered for translation (Horvathova, 2014: 102).

The most frequent and optimal from the viewpoint of the semantic equivalence strategy of translating the studied lexical units is represented by loan translation:

- $\quad$ Statue of Liberty (Statuya Svobody), Giant's Causeway (Tropa Velikana), Gosudarstvennyy Ermitazh (State Hermitage), Korolevskiy zamok (Royal Castle), Krasnodarskiy kraevoy teatr kukol (Krasnodar Regional Puppet Theater), etc.

When the object's name is derived from a proper name or a geographic name, the possibilities of loan translation are limited, but in these cases the descriptive translation may serve as a substitution of semantic explication:

- Kostomuksha municipal museum ${ }^{18}$ (comes with the note City/Settlement Kostomuksha);

- $\quad$ Bomaris, kak i drugie zamki Anglii etogo perioda, byl postroen korolem Eduardom I dlya usileniya vlastiv Uelse. Stroitelstvo nachalos v 1295 godu pryamo posredi bolota. "Bo Mareys" $v$ perevode oznachaet "Krasivoe boloto",19.

\footnotetext{
84831_heatonhall

http://www.visitmanchester.com/what-to-do/countryroyalpark/MAN-

${ }^{16} \mathrm{http}: / /$ www.touropia.com/tourist-attractions-in-london/

${ }_{18}^{17} \mathrm{http} / / / \mathrm{www} . v i s i t t h e u s a . c o m / u s a / e x p e r i e n c e s / f / f l o r i d a / k e n n e d y-s p a c e-c e n t e r . a s p x$ 18

http://www.ticrk.ru/en/regions/region/settlement/sights/sight/?CID=7525\&PID=838

$5 \& \mathrm{ID}=16973$

${ }^{19} \mathrm{http} / / /$ allcastle.info/europe/england/003
} 
- Trafalgarskaya ploshchad - samaya izvestnaya londonskaya ploshchad, kotoraya pervonachalno nosila imya korolya Vilgelma IV, no zatem byla pereimenovana $v$ chest pobedy Anglii $v$ Trafalgarskoy bitve $e^{20}$.

Disregard of these techniques of interlinear and loose translation ensuring the localization of foreign-language elements can reduce the information content and weaken both cognitive and appellative functions of a text. Providing unadapted foreign-language insertions exemplifies the pragmatically unacceptable foreignization of the context:

Otdykhayushchim s detmi pridetsya po dushe poseshchenie parka razvlecheniy Canada's Wonderland, karta kotorogo otrazhena na sayte www.canadaswonderland.com: tam imi budut obnaruzheny dinozavry (gostyam predlagayut posmotret na 40 eksponatov $v$ naturalnuyu velichinu), detskiy gorodok s igrovymi ploshchadkami, semeynye attraktsiony ("Antique Carousel", "Flying Eagles", "Klockwerks", "Silver Streak", "The Rage"), zakhvatyvayushchie ("Behemoth", "Backlot Stunt Coaster", "Leviathan", "Flight Deck", "Night Mares") i detskie ("Blast Off!", "Frequent Flyers", "Jumpin' jet", "Snoopy's Revolution", "Sugar Shack", "The Pumpkin Patch"), a takzhe akvapark (raspolagaet lenivoy rekoy, volnovym basseynom, Splash Island Kiddie Pool, gorkami "Body Blast", "Barracuda Blaster", "Riptide Racer", "Typhoon", "Whirlwinds" i drugimi $)^{21}$.

As we can see, there are too many original English words in this Russian encyclopedic text which meanings are not explicated for Russian readers that impedes understanding the experience they are going to have at the mentioned attractions.

According to N.V. Filatova, the specially selected onomastics serves as expressive means in a tourist text (Filatova, 2014: 42). Proper names are among the linguistic units that are susceptible to socio-cultural symbolization and, as a consequence, they are capable of conveying the conceptual and emotional content in a laconic form (Tomskaya, 2012: 269). S. Vlakhov and S. Florin in their work The Untranslatable in Translation give a good example connected with transcribing journals' and newspapers' names. According to the authors, the meanings of proper names which are clear to the reader of the original, should be transferred to the mind of a translation version reader as well, otherwise, all the information they retrieve from the title Pravda consists only in the fact that it is a newspaper or a journal, while the seme "truth" remains undeciphered (Vlahov \& Florin, 2012: 212). This example is very illustrative from the viewpoint of foreign names of environmental and cultural objects functioning in every tourist text. Understanding is not separated from the evaluation, they constitute a single and simultaneous integral act (Bakhtin, 1979), and in respect of the tourist text, we suppose a much greater responsibility of proper names as lexical means characterized by a high degree of appellation and being one of the main tools for achieving communicative and pragmatic effect. In this respect the localization strategy can provide a tourist's full immersion in the atmosphere of the place, necessity to feel him/herself as a participant of a certain event (Gureeva et al., 2016: 98).

\footnotetext{
${ }^{20} \mathrm{http}: / /$ euroupe-turizm.ru/england/37-trafalgarskaya-ploschad.html

${ }^{21} \mathrm{http} / / / \mathrm{www}$. votpusk.ru/story/article.asp?ID=16081
} 
Partial preservation of seme composition, which takes place in the case of combinations "transcription / transliteration + loan translation" (and vice versa), may also be misleading, since, firstly, this hybridization prevents the transfer of the full semantic meaning of lexical units, and, secondly, it is does not provide the original name, which can serve as a tourist guide. The name of the Saviour Tower (original name Spasskaya bashnya) at the Kazan online travel portal is translated by half-loan Spasskaya Tower, and the transliterated element creates a cognitive gap despite the subsequent etymological explanation:

The Spasskaya Tower got its name from the 'Image of Edessa' Icon (Spas Nerukotvorniy) ${ }^{22}$

The origin of the word Spasskaya from the name of the Savior Holy Face Icon (Spas Nerukotvorniy) is explicated for the foreign readers only in case of their awareness of the biblical plot 'Image of Edessa'. Otherwise, the disregard of translation loan Saviour Tower leads to the absence of the image of the Savior as a name's main conceptual element in the English-language version. Many such "misleading" examples are found in Russian and English secondary texts: Rurik's gorodishche ${ }^{23}$ instead of Rurik's Settlement; Church of Vera, Nadezhda, Lyubov (Faith, Hope and Love) and Their Mother Sophia ${ }^{24}$ instead of St. Sofia Russian Orthodox Church; Vechnaya Slava monument ${ }^{25}$ instead of Eternal Glory Monument; Kingz-Park ${ }^{26}$ instead of Korolevsky park; attraktsion Edge Walk ${ }^{27}$ instead of attraktsion "Po krayu bezdny", and others.

\section{Hypothesis}

Against the background of the described duality, which is manifested in the combination of domestication and foreignization trends, we put forward the important issue on the necessity to provide two nominations of tourist destinations in secondary texts - a translated and an original name. N.V. Filatova studies the use of foreign words (in the form of both original-language lexis and transcriptions) in tourism discourse giving examples of squares' bilingual names: ploshchad Svyatogo Stefana (Stephansplatz); ploshchad In-der-Burg (Filatova, 2014: 46). This tactics is often used in the process of tourist texts' translation, but it is characterized by spontaneity and the lack of fundamental grounds:

- Londonskiy glaz (London Eye) - odno iz krupneyshikh kolyes obozreniya $v$ mire ${ }^{28}$;

- Yorkvikskiy tsentr vikingov (Jorvik Viking Centre) $)^{29}$;

- Cathedral of the Transfiguration (Preobrazhensky Kafedralny Sobor $)^{30}$

${ }^{22}$ http://gokazan.ru/places/spasskaya-bashnya-kazanskogo-kremlya/

http://visitnovgorod.com/novgorod/discover_novgorod/The_birthplace_of_Russia.ht $\mathrm{ml}$

${ }^{24} \mathrm{http} / / /$ /belgorodtur.ru/en/about/attractions/sacred-places-and-objects.html

${ }^{25} \mathrm{http}: / / \mathrm{www}$. turtmb.ru/leftmenu/touristattraction-copy/

${ }^{26} \mathrm{http}: / /$ www.votpusk.ru/country/dostoprim_info.asp?ID=2240

${ }^{27} \mathrm{http}: / / \mathrm{www}$. votpusk.ru/story/article.asp?ID=16081

${ }^{28} \mathrm{http}: / / \mathrm{www}$. edemvlondon.ru/london-eye/

${ }^{29} \mathrm{https}: / / \mathrm{www} . v i s i t b r i t a i n . c o m / r u / r u / y o r v i k s k i y-c e n t r-v i k i n g o v$

${ }^{30} \mathrm{http}$ ://belgorodtur.ru/en/about/attractions/sacred-places-and-objects.html 
- Tsenitelyam istorii navernyaka ponravyatsya zamok Berkli (Berkeley Castle), znamenityy dvorets Blenkheym (Blenheim Palace) - rodovoe gnezdo gertsogov Malboro, gde rodilsya Uinston Cherchill. A takzhe abbatstvo Tyuksberi (Tewkesbury Abbey) $)^{31}$.

We are going to take an attempt of justifying this tactics from the theoretical and practical points of view and indicating the reasons for its necessity and logic.

\section{Substantiation}

\section{Lack of unified approaches to translation}

In February 2016 the chairman of the Committee for Culture of St. Petersburg, Konstantin Sukhenko reported on the large-scale project "Translation of the city". The key idea of this project is to provide official translation of names of all streets, public institutions, memorable and geographical objects by 2018 for ensuring the convenient environment for foreign tourists (cit. from News Dale, 2016). The initiation of the project and the recognition of its unprecedented nature revealed the absence of approved translations of microtoponyms not only within a single city, but in Russia as a whole.

The exceptions include the names of some world-famous tourism objects of art and culture which acquired the terminological feature of internationality and have fixed foreign-language versions (indicated at the official multilingual websites of these objects), the use of which does not create perception problems. For example, the English name of the Bolshoy Teatr (Bolshoi Theatre) is so familiar to the representatives of the English linguaculture that it is used in journalist and advertising texts without any explanations:

The Bolshoi Ballet performed Saturday in Cuba after a 30-year absence $^{32}$

The Bolshoi will be performing Jean-Christophe Maillot's Taming of the Shrew ${ }^{33}$

Russian-speaking recipients are familiar with such realia as Stounkhendzh (Stonehenge) and Big Ben (Big Ben), so they also function in Russian media without any explanations or comments:

- Stounkhendzh iznachalno byl vozveden $v$ Uelse $i$ lish posle doistoricheskie stroiteli razobrali ego $i$ "peretashchili" na territoriyu sovremennogo grafstva Uiltshir ${ }^{34}$;

- Zhiteli Londona davno uzhe ne morshchatsya, kogda slyshat ot turistov "bashnya Big Ben",35.

However, as a rule, there are no uniform translations of microtoponyms even within the same information portal of a city. D. I. Ilyin is right to note that proper names are the universal means of nominating objects which performs a spaceorganizing role in the region's geographical characteristics (Ilyin, 2010: 65). Taking into account this definition, the absence of a unified approach to the verbal representa-

\footnotetext{
${ }^{31}$ https://www.visitbritain.com/ru/ru/england/central-england/kotsuolds

$32 \mathrm{http}: / /$ www.havanatimes.org/?p=19796

$33 \mathrm{http} / / /$ www.roh.org.uk/news/bolshoi-ballet-to-return-to-the-royal-opera-house-insummer-2016

${ }^{34} \mathrm{https}: / /$ rg.ru/2015/12/07/kamni-site-anons.html

${ }^{35} \mathrm{http}: / /$ masterok.livejournal.com/623395.html
} 
tion of geographical space objects may lead to nominative inconsistencies. For example, the Volgograd tourism website ${ }^{36}$ contains the hypertext on the tour of the Mamai's Barrow memorial complex, where we can find two different versions of this name's translation into English - a transliterated Mamaev Kurgan and a loan Mamai Hill. We doubt the adequacy of using two different word-for-word translations within a given context as well as the semantic equivalence of words Kurgan and Hill, the latter of which does not contain the seme "grave". These names seem to be arguable from the standpoint of cognitive expectations of the English-speaking readers and emphasize the lack of common approaches to the translation of toponyms. This problem leads to the existence of different translations in English-language sources Mamaev Barrow ${ }^{37}$, Mamai's Barrow ${ }^{38}$, Mamayev Hill ${ }^{39}$.

The translation of English microtoponyms is also a major difficulty connected with the fact that the tourist websites of such countries as the U.S., Australia, Canada, Great Britain rarely have a Russian-language page. As a consequence, Russian tourists refer to encyclopedic articles, guidebooks, advertising materials as a main source of information on foreign cultural attractions. This information is represented on Russian tour operators' websites which are also characterized by diversified translated titles of popular objects: for example, London Eye is translated as Londonskiy glaz ${ }^{40}$, Oko Londona ${ }^{41}$, Londonskoe oko ${ }^{42}$. Translator's work with parallel texts and the choice of optimal variant of the translation is also complicated by the lack of Russianlanguage information about some of the other countries' attractions such as Britannia Panopticon Music Hall, Somerset Place, Bristol Old Vic Theatre, etc. even in the world-famous Wikipedia database.

Albert Square, an area located in the city of Manchester (England), is translated in different ways at the two Russian tourist websites: Albert-Skver ${ }^{43}$ and Ploshchad Alberta $^{44}$, but unlike the above example of London Eye, these variants have a significant difference at the denotative level. Skver is a small landscaped plot of land, representing an element of square's design. The use of microtoponyms skver and ploshchad as absolute synonyms seems to be inadequate taking into account the given definition, despite the origin of the word skver from the English 'square'.

In the absence of multilingual dictionaries of microtoponyms the translator's solution becomes a particular case and has a multivariate nature. Thus, providing an original name guarantees certain fixity of a lexical unit, its authenticity, independent of translations and ensuring the easy search for detailed information about a specific tourist site.

\section{Verbal semiotics of cultural space}

\footnotetext{
${ }^{36} \mathrm{http}: / /$ www.visitvolgograd.info/eMamaevKurgan.htm

${ }^{37} \mathrm{http}: / /$ www.r-tg.com/volgograd/283.html

${ }^{38} \mathrm{http}: / / \mathrm{www}$. estockphoto.com/results.asp?image=2001-285098-01

${ }^{39} \mathrm{http} / / / \mathrm{www}$.historvius.com/mamayev-hill-650/

${ }^{40} \mathrm{http}: / /$ tonkosti.ru/Лондонский_глаз

${ }^{41} \mathrm{http} / / / \mathrm{www}$. votpusk.ru/country/dostoprim_info.asp?ID=2457

${ }^{42} \mathrm{http}: / /$ london10.ru/article/londonskoe-oko-poleznaya-informaciya

${ }^{43} \mathrm{http} / / /$ tonkosti.ru/Манчестер

${ }^{44} \mathrm{http} / / / \mathrm{www}$. rutraveller.ru/place/30770
} 
The term "linguascape" was firstly used to refer to the written form of the language used in public places - on road signs, billboards, street signs, city facilities, shops, etc. (Landry \& Bourhis, 1997: 23-25). Yu. M. Lotman considers a city to be the area of cultural bilingualism, providing semiotic contacts between the two worlds, and gives it a function of the semiosphere border, the nature of which is always bilingual (Lotman, 1992). Within the framework of the aforementioned project "Translation of the City" it is planned not only to approve official English names of the urban objects, but also to ensure the bilingual verbal semiotics of the city, which, in the light of the Yu.M. Lotman's judgment, will serve as a marker of the transition to a different semiotic space and the means of maintaining cultural contacts. Today Russian cities and most of English-speaking countries do not have such markers, and we recognize the need of creating them in the space of tourism websites.

Since the choice of language means in the texts of localized versions is conditioned by their functionality (Novikova, 2015: 474), we should take into account not only informative and cognitive functions but also a referential one, which was a peculiar feature of the first sample of guidebook - the itinerary. In our opinion, the reference function is very important when making decision on giving two microtoponyms in secondary texts - an original and a translated. Loan translation without referring to original name may result in major obstacles and failures in the process of intercultural communication since discourse participants cannot denote a certain tourist object. The main purpose of the guidebook is to serve as a tourist guide and "to ensure the adaptation to the new linguacultural space" (Edensor, 2001: 73; Filatova, 2014: 39). This purpose is realized in the hypertext space of tourist portal, and in some cases, on the agencies' websites containing detailed milestone descriptions of advertised routes and excursions. Tourists' orientation by signs, maps, direction in the space of other cultures is actually an important aspect of the development of glocal cities, and a tourist website serving as such a guide may help to easily identify the surrounding objects and therefore ensure the convenient staying in a foreign country.

\section{Tourist's linguascape}

$\mathrm{K}$. Thurlow and A. Jaworski develop the concept of linguascape and consider it to be the expansion of the "tourist gaze" theory, proposed by J. Urry (Urry, 2002). The authors emphasize the important role of language as an element of tourist experience and inculturation (Thurlow \& Jaworski, 2011: 289). On the example of oral interactions in the tourist discourse, the authors demonstrate the recognition of local languages' value by tourists, which act as the markers of authenticity and originality along with the unfamiliar landscapes, and arouse a sense of belonging to a cosmopoli$\tan$ multicultural global community. According to the authors of the world famous series of guidebooks DK Eyewitness Travel Guides, the readers wish to learn more foreign phrases and information about the language of the country they visit (cit. from Thurlow \& Jaworski, 2007).

The research carried out by Stephania Gandin and aimed to reveal differentiating features between original and translated English texts on tourism, indicated a high percentage of "unclassified" items which are not words of the English lexicon (Gandin, 2013). Providing quantitative indicators without lexical specification of foreign words, the author points out the trend of foreignization of translated tourism discourse connected with the phenomenon of interference. Lexical interference which is understood as the intervention of the vocabulary of one language system to another (Alimov, 2005: 31), implies the direct borrowing of foreign word (in the original form or by means of transcription / transliteration), which becomes the "transitional" in a 
translated text (Komissarov, 1999: 127). According to G. Turi, who developed the concept of "transitional" language (interlanguage), interference can be characterized not only by destructive, but by constructive properties as well (Toury, 1980), and in our case, it may serve as a means of the aesthetic influence on the addressee. N.V. Filatova notes the expressiveness of tourism texts which can be achieved by combining two codes (Filatova, 2014: 46), G. Dann connects this phenomenon with the use of languaging verbal technique, understood as "the manipulation of national language" aimed to make the text locally coloured (Dann, 1996: 183-185). M. Petillo analyzes this technique exemplified by the guidebook translated from Italian into English and highlights its importance in terms of pragmatic and didactic goals of providing tourists with the vocabulary necessary for living in a foreign country (Petillo, 2012: 253-256). Thus, the fragments of local languages bear the "concept of personal enrichment" (Bourdieu, 1991), and "the tendency of translators to create assimilated secondary texts leads to a gradual loss of original markers of "otherness", thereby removing intercultural distances (Maslennikova, 2014: 25).

\section{Conclusion}

The research revealed that the functions of microtoponyms in the hypertext space of tourism discourse are not limited by information sharing, but include such important elements of pragmatics as cognitive, appellative, and aesthetic potential. Techniques of loan and descriptive translation ensure the preservation and linguacultural adaptation of the original semantic elements that express the important sociological and ethnocultural meanings. In our view, localization of the studied lexical units should consist not only in the explication of semantics, but also in enabling the identification of surrounding objects in foreign and virtual spaces.

We have identified three reasons of the need to supplement the translated microtoponyms in tourist hypertexts with original names:

1. absence of approved translations of the majority of English and Russian names of urban sites;

2. the need for the tourist guides in the verbal semiotic space;

3. recognition of the value of linguacultural potential as a means of realizing the aesthetic and didactic functions of the text.

In these conditions the original microtoponyms guarantee certain fixity of lexical units, their authenticity independent of translations and ensuring easy search for detailed information about a specific tourist site; help tourists to identify the surrounding objects and therefore ensure the convenient staying in a foreign country; and, finally, enrich tourist experience linguistically.

Thus, the localization of tourist hypertexts should be considered not only in terms of domestication and integration of foreign-language cultural landmarks, but also taking into account the reference function as well as the motivations of tourists, often associated with the pursuit of authenticity and originality.

The article is prepared with the financial support of the Russian Foundation for Humanities, regional contest "Volzhsky Lands in the Culture History of Russia", project No. 15-14-34001 Linguistic and Translatology Logistics of Multilingual Webportal: Regional Guide within Globalization (Volgograd and Volgograd Region).

\section{Bibliographic references}


ALIMOV, V.V. 2005. Interferentsiya $\mathrm{v}$ perevode (na materiale professionalnoorientirovannoy mezhkulturnoy kommunikatsii i perevoda $\mathrm{v}$ sfere professionalnoy kommunikatsii): avtoreferat diss. ... doktora filol. nauk. Moscow, $40 \mathrm{p}$.

ANDROUTSOPOULOS, J. 2010. Localizing the Global on the Participatory Web. In: The Handbook of Language and Globalisation, pp. 203-231.

BAKHTIN, M.M. 1979. Estetika slovesnogo tvorchestva. Moscow, Iskusstvo.

BATYUKOVA N.A. 2011. Mnogoyazychnaya lokalizatsiya v sovremennom virtualnom prostranstve. In: IV Mezhdunarodnaya virtualnaya konferentsiya po rusistike, literature i kulture "Obrazovatelnye tekhnologii v virtualnom lingvokommunikativnom prostranstve": Sbornik nauchnykh dokladov. USA, VERMONT, MIDLBERI KOLLEGE, 2-4 March, pp. 42-46.

BOURDIEU, P. 1991. Language and Symbolic Power. Edited by John B. Thompson. Translated by Gino Raymond and Matthew Adamson. Cambridge: Polity Press. CHARFAOUI, E.: Komunikatívno-pragmatické a lingvokultúrne charakteristiky reklamného textu. Bratislava: Univerzita Komenského, 2014. ISBN 978-80-2233712-0.

CHARFAOUI, E. - MITYAGINA, V. A.: Formirovanije terminosystemy menedžment v koordinatach nemeckogo, slovackogo i russkogo jazykov. In: Jazykovedné, literárnovedné a didaktické kolokvium 24. Bratislava: Z-F Lingua, 2014. pp. 91-99, 203-212 ISBN 978-80-89328-96-3.

CHARFAOUI, E. - OPALKOVA, J.: Dynamika v odbornej lexikografickej praxi. In: Acta Facultatis Philosophical Universitatis Prešoviensis: Jazykový zborník, Vol. 48. Prešov : Filozofická fakulta Prešovskej univezity, 2013. pp. 477-488. ISBN 978-80555-0890-0.

EDENSOR, T. 2001. Performing tourism, staging tourism. In Tourist studies, vol. 1, pp. 59-81. Available online: http://www.nyu.edu/classes/bkg/tourist/a019896.pdf

FILATOVA, N.V. 2014. Diskurs sfery turizma v pragmaticheskom i lingvisticheskom aspektakh: diss. ... kandidata filol. nauk. Moscow.

GUREEVA A.A. - NOVIKOVA E.Yu. - MITYAGINA V.A. 2016. Guideinterpreter's language identity as an excursion discourse factor. In: XLinguae, vol. 9, n. 2. pp. 90 - 102. ISSN 1337-8384.

HORVATHOVA, B. 2014. Approaches to Translating English Idioms into Foreign Languages. In: Proceedings of International Conference Language, Literature and Culture in Education 2014 (Nitra, 7-9 May, 2014). Nitra, pp. 96-104.

ILYIN, D.Yu. 2010. Toponimikon regiona $\mathrm{v}$ aspekte izucheniya funktsionalnosemanticheskikh protsessov. In: Onomastika i obshchestvo: yazyk i kultura: materialy Pervoy Vserossiyskoy nauchnoy konferentsii (Tambov, 14-15 oktyabrya 2010 g.). otv. red. A.S. Shcherbak. Tambov, TGU im. G.R., pp. 64-67.

JIMENEZ-CRESPO, M.A. 2016. What is (not) web localization in translation studies: A prototype approach. In: The Journal of Internationalization and Localization, vol. 3, n. 1, pp. 38-60.

KOMISSAROV, V.N. 1999. Obshchaya teoriya perevoda : ucheb. posobie. Moscow, CheRo, $136 \mathrm{p}$.

LANDRY, R. - BOURHIS, R. 1997. Linguistic Landscape and Ethnolinguistic Vitality. An Empirical Study. In: Journal of Language and Social Psychology, vol. 16, n. 1, pp. 23-49.

LOTMAN, Yu.M. 1992. Statyi po semiotike i topologii kultury. In Izbrannye statyi. Available online: http://www.gumer.info/bibliotek_Buks/Culture/Lotm/01.php

MASALIMOVA, A. R. - IKRAMOVA, G. D. - SHAIDULliNA, A. R. GUBAIDULliNA, G. T. - APRAKSINA, N. D. 2014. Distant in-company foreign 
language learning involving university student-tutors. In: American Journal of Applied Sciences, 11, 1123-1127.

MASALIMOVA, A.R. 2015. Role of foreign language teacher shaping students' research skills. In: Asian Social Science, 11 (4), pp. 135-140.

MASLENNIKOVA, E.M. 2014. Assimilyatsiya kak tendentsiya sovremennogo khudozhestvennogo perevoda. In: Vestnik Chelyabinskogo gosudarstvennogo universiteta, n. 6 (335), pp. 22-25.

MITYAGINA, V.A. 2014. Perevod v formirovanii turisticheskogo internet-diskursa. In: Media- i mezhkulturnaya kommunikatsiya $\mathrm{v}$ evropeyskom kontekste: materialy Mezhdunarodnoy nauchno-prakticheskoy konferentsii. Stavropol, Izd-vo SeveroKavkazskogo federalnogo un-ta, pp. 346-348.

MITYAGINA, V.A. 2015. Turisticheskiy internet-diskurs: nominativnye oshibki kak negativnyy faktor mezhkulturnoy kommunikatsii. In: Vestnik Moskovskogo gosudarstvennogo lingvisticheskogo universiteta: Diskurs kak sotsialnaya deyatelnost: prioritety i perspektivy, vol. 6 (717), pp. 424-435.

NOVIKOVA, E.Yu. 2015. Diskursivnye kharakteristiki "glokalnogo goroda" na gorodskom internet-portale. In: Vestnik Moskovskogo gosudarstvennogo lingvisticheskogo universiteta: Diskurs kak sotsialnaya deyatelnost: prioritety i perspektivy, vol. 6 (717), pp. 467-477.

Obyekty gorodskoy sredy v Peterburge perevedut na angliyskiy yazyk k 2018 godu. In: News Dale: Ezhednevnoe Internet-izdanie, 29.02.2016. Available online: http://www.newsdale.ru/article/show/35279.

PAVLIKOVA, M. 2017. Consciousness of anxiety in literary work of Don DeLillo. In: XLinguae, vol. 10, n. 1, pp. 62-69. ISSN 1337-8384.

PETILLO, M. 2012. Translating cultural references in tourism discourse: the case of the Apulian region. In: Altre Modernita, pp. 248-263.

PYM, A. 2014. Exploring Translation Theories. $2^{\text {nd }}$ ed. N. Y.: Routledge, 255 p.

SHADRIN V.I. 2015. Lokalizatsiya informatsionnogo teksta i problema degumanizatsii deyatelnosti perevodchika. In: Strukturnaya i prikladnaya lingvistika: mezhvuz. sb. Saint Petersburg, Izd-vo S.-Peterb. un-ta, vol. 11, pp. 50-59.

SHURLINA, O.V. 2014. Trudnosti "lokalizatsii" kak lingvokulturnoy adaptatsii tekstov programmnogo obespecheniya. In: Vestnik VGU. Seriya: lingvistika i mezhkulturnaya kommunikatsiya, n. 1, pp. 83-87.

THURLOW, C. - JAWORSKI, A. 2007. Scripting Global Discourse: The Commodification of Local Linguacultures in Tourist Guidebooks. In: International Communication Association, TBA, San Francisco, CA, May 23. Available online: http://citation.allacademic.com//meta/p_mla_apa_research_citation/1/7/0/4/7/pages 17 0478/p170478-1.php.

THURLOW, C. - JAWORSKI, A. 2011. Tourism discourse: languages and banal globalization. In: Applied Linguistics Review, vol. 2, pp. 285-312.

TOMSKAYA, M.V. 2012. Antroponimy kak rezultat gibridizatsii. In: Semioticheskaya geterogennost yazykovoy kommunikatsii: teoriya i praktika. Moscow, MGLU, pp. 269-276.

TOURY, G. 1980. In Search of a Theory of Translation. TelAviv, $159 \mathrm{p}$.

URRY, J. 2002. The Tourist Gaze. - 2nd ed. London: Sage. 183 p.

USACHEVA, A.N. 2012. Lokalizatsiya giperteksta kak innovatsionnaya forma mezhkulturnoy kommunikativnoy praktiki. In: Kommunikativnye aspekty sovremennoy lingvistiki i lingvodidaktiki: Materialy mezhdunarodnoy nauchnoy konferentsii, g. Volgograd, 8 fevralya 2012g. Volgograd, Izd-vo VolGU, pp. 131-134. 
VAJICKOVA, M. 2015. Theoretische Grundlagen stilistischer Textanalyse. Nümbrecht: Kirsch-Verlag. ISBN 978-3-943906-18-9.

VASILYEVA, Yu.A. 2016. Interpretatsiya etnokulturnykh komponentov semioticheskogo prostranstva goroda (na primere tyurkskikh ergonimov Astrakhani). In: Vestnik Kostromskogo gosudarstvennogo universiteta im. N.A. Nekrasova, vol. 22 , no. 1 , pp. $140-143$.

VLAKHOV, S.I. - FLORIN, S.P. 2012. Neperevodimoe v perevode. Moscow, R.Valent, $406 \mathrm{p}$.

10 Top Tourist Attractions in London. Retrieved from:

http://www.visitmanchester.com/what-to-do/countryroyalpark/MAN-

84831_heatonhall; (accessed July 23, 2016)

Arkheologi: Stounhendzh "peretashchili" v Uiltshir na sanyakh // Rossiyskaya gazeta. Retrieved from: https://rg.ru/2015/12/07/kamni-site-anons.html. (accessed July 25, 2016)

Big Ben. Live Journal. Retrieved from: http://masterok.livejournal.com/623395.html; (accessed July 26, 2016)

Bolshoi Ballet to return to the Royal Opera House in summer 2016 // Royal Opera House. Retrieved from: http://www.roh.org.uk/news/bolshoi-ballet-to-return-to-theroyal-opera-house-in-summer-2016; (accessed August 6, 2016)

Bomaris Castle // AllCastle. Retrieved from: http://allcastle.info/europe/england/003; (accessed July 25, 2016)

Cotswolds. Welcome to Great Britain. Retrieved from:

https://www.visitbritain.com/ru/ru/england/central-england/kotsuolds; (accessed July 26, 2016)

Havana Times e-newspaper. Retrieved from: http://www.havanatimes.org/?p=19796; (accessed July 26, 2016)

Heaton Hall. Visit Manchester. Retrieved from:

http://www.visitmanchester.com/what-to-do/countryroyalpark/MAN-

84831_heatonhall; (accessed July 25, 2016)

Interesting Places in Toronto. Votpusk.ru. Retrieved from:

http://www.votpusk.ru/story/article.asp?ID=16081; (accessed July 25, 2016)

Interesting places in Toronto // Votpusk.ru. Retrieved from:

http://www.votpusk.ru/story/article.asp?ID=16081; (accessed July 25, 2016)

Jorvik Viking Centre. Welcome to Great Britain. Retrieved from:

https://www.visitbritain.com/ru/ru/yorvikskiy-centr-vikingov; (accessed July 25,

2016)

Karelia Tourist Portal. Retrieved from:

http://www.ticrk.ru/en/regions/region/settlement/sights/sight/?CID=7525\&PID=8385

\&ID=16973; (accessed July 23, 2016)

Kennedy Space Center. Visit the USA. Retrieved from:

http://www.visittheusa.com/usa/experiences/f/florida/kennedy-space-center.aspx;

(accessed July 25, 2016)

Kings Park. Votpusk.ru. Retrieved from:

http://www.votpusk.ru/country/dostoprim_info.asp?ID=2240; (accessed July 25,

2016)

London Eye. Edem v London.ru. Retrieved from:

http://www.edemvlondon.ru/london-eye/; (accessed July 25, 2016)

London Eye. Tonkosti turizma guidebook. Retrieved from:

http://tonkosti.ru/Лондонский_глаз; (accessed August 1, 2016) 
Mamaev Kurgan. Visit Volgograd.info. Retrieved from:

http://www.visitvolgograd.info/eMamaevKurgan.htm; (accessed August 1, 2016)

Mamayev Hill. Historvius discover more. Retrieved from:

http://www.historvius.com/mamayev-hill-650/; (accessed August 1, 2016)

Russia, Volgograd, memorial 'Mamai's barrow'. Image No. 2001-285098-01 // e-stock

photo. Retrieved from: http://www.estockphoto.com/results.asp?image=2001-285098-

01; (accessed August 6, 2016)

Saint Ioasaph of Belgorod. Tourism Portal of Belgorod City. Retrieved from:

http://belgorodtur.ru/en/about/attractions/sacred-places-and-objects.html; (accessed

July 25, 2016)

Tourism Portal of Kazan. Retrieved from: http://gokazan.ru/places/spasskaya-

bashnya-kazanskogo-kremlya/; (accessed July 25, 2016)

Tourism Portal of the Tambov Region. Retrieved from:

ww.turtmb.ru/leftmenu/touristattraction-copy/; (accessed July 25, 2016)

Trafalgar Square. Travel and Tourism. Retrieved from: http://euroupe-

turizm.ru/england/37-trafalgarskaya-ploschad.html; (accessed July 23, 2016)

Veliky Novgorod - the Birthplace of Russia // Visit Novgorod. Retrieved from:

http://visitnovgorod.com/novgorod/discover_novgorod/The_birthplace_of_Russia.ht ml; (accessed July 23, 2016)

Volgograd. Russia Travel Group. Retrieved from: http://www.r-

tg.com/volgograd/283.html; (accessed August 1, 2016)

London Eye. Votpusk.ru. Retrieved from:

http://www.votpusk.ru/country/dostoprim_info.asp?ID=2457; (accessed August 6,

2016)

London Eye. Useful information. London10.ru. Retrieved from:

http://london10.ru/article/londonskoe-oko-poleznaya-informaciya; (accessed August 1, 2016)

Manchester. Tonkosti turizma guidebook. Retrieved from:

http://tonkosti.ru/Манчестер; (accessed August 1, 2016)

Albert square. Rutraveller guidebook. Retrieved from:

http://www.rutraveller.ru/place/30770; (accessed August 6, 2016)

Words: 5350

Characters: 32621 (19, 76 standard pages)

Irina D. Romadina

Prof. Vera A. Mityagina, DrSc

Department of Translation Theory and Practice

Institute of Philology and Intercultural Communication

Volgograd State University

Prospect Universitetsky, 100, 400062, Volgograd

Russia

tipp@ volsu.ru 